\title{
KOLABORASI APLIKASI, POP-UP, DAN MOVABLE BOOK UNTUK MEMBUAT MEDIA PEMBELAJARAN 3D BAGI GURU-GURU DI DESA GEGER
}

\author{
Cahyo Hasanudin'1), Novi Mayasari' ${ }^{2)}$, Kundharu Saddhono ${ }^{3)}$, \\ Ega Wahyu Mahardika ${ }^{4)}$ \\ ${ }^{1,4}$ Pendidikan Bahasa dan Sastra Indonesia, FPBS, IKIP PGRI Bojonegoro \\ ${ }^{2}$ Pendidikan Matematika, FMIPA, IKIP PGRI Bojonegoro \\ ${ }^{3}$ Pendidikan Bahasa Indonesia, FKIP, Universitas Sebelas Maret Surakarta
}

\begin{abstract}
Abstrak
Desa Geger memiliki jenjang pendidikan pos paud hingga madrasah aliyah. Namun, lengkapnya jenjang pendidikan di Desa Geger ini belum mengakomodir pengetahuan dan keterampilan guru-guru dalam membuat media pembelajaran 3D. Selain itu, hasil analisis SWOT menunjukkan bahwa guru-guru di desa Geger perlu mendapat pelatihan. Oleh karena itu, tim pengabdi merumuskan sebuah tujuan pengabdian yaitu 1) Ingin meningkatkan pengetahuan tentang media pembelajaran $3 \mathrm{D}, 2$ ) ingin meningkatkan keterampilan dalam membuat media pembelajaran 3D bagi guru-guru di Desa Geger, Kecamatan Keduangadem, Kabupaten Bojonegoro. Metode Pelaksanaan pelatihan secara tatap muka dan daring dengan menggunakan aplikasi zoom sedangkan pelaksanaan pelatihan dimulai dari tahap awal, tahap inti, dan tahap akhir. Ketiga tahapan ini berfungsi untuk mengukur pengetahuan dan keterampilan mitra pengabdian. Cara mengukurnya yaitu membandingkan hasil pretes dan postes. Soal pretes dan postes terlebih dahulu sudah divalidasi oleh tiga orang validator. Hasil pengabdian menunjukkan bahwa ada peningkatan pengetahun dan keterampilan mitra pengabdian. Simpulan pengabdian ini adalah 1) pengetahuan mitra pengabdian tentang media pembelajaran 3D meningkat 57\%. Peningkatan ini dapat dilihat dari perbandingan rerata hasil pretes sebesar $38 \%$ dan rerata hasil postes sebesar 94\%, 2) keterampilan mitra pengabdian dalam membuat media pembelajaran 3D meningkat $70 \%$. Pengingkatan ini dapat dilihat dari perbandingan rerata hasil pretes sebesar 25\% dan rerata hasil postes sebesar $95 \%$. Kata Kunci: Aplikasi, Pop-up, movable book, media pembelajaran 3D,
\end{abstract}

\begin{abstract}
Geger Village had many school buildings starting from kindegarten until Islamic Senior High School. However, it had not accomodated the teachers' knowledge and skills in creating $3 D$ learning media. In addition, the results of SWOT analysis showed that the teachers needed to get such kind of trainings. Therefore, the teams of this community service formulated the aims of service were 1) to increase teachers' knowledge about learning media, 2) to increase teachers' skills in creating $3 D$ learning media. The training methods were face-to-face training and online training by using Zoom apps. The stages of training started from initial stage, main stage, and final stage. These three stages had a function to measure the partners' knowledge and skills. The way was by comparing the results of pre-test and post-test. The test questions had been validated by the three validators. The partners of this community service were all of the teachers in Geger Village, Kedungadem, Bojonegoro who acted as the participants of this service. The results of this community service showed that teachers' knowledge and skills were increased. The conclusions of this service were 1) the teachers' knowledge about 3D learning media had been increased 57\%. This increase could be be viewed from the comparison between the average value of pre-test result was $38 \%$ and the average value of post-test was 94\%, 2) the teachers' skills in creating 3D learning media had increased $70 \%$. This increase could be viewed from the comparison between the average value of pre-test result was 25\% and the average value of post-test was $95 \%$.
\end{abstract}

Keywords: Apps, Pop-up, Movable book, 3D learning media

Correspondence author: cahyo hasanudin cha.sanu.88@gmail.com, Bojonegoro, Indonesia (c) (i) $\$$

This work is licensed under a $C C-B Y-N C$ 


\section{PENDAHULUAN}

Desa Geger merupakan desa terbarat dari Kecamatan Kedungadem dan berbatasan langsung dengan Desa Wedoro Kecamatan Sugihwaras, sehingga Desa Geger dapat dijuluki sebagai desa perbatasan yang menghubungan antara Kecamatan Kedungadem dan Kecamatan Sugihwaras. Desa Geger terletak pada koordinat 7¹7'29.0"S $111^{\circ} 59^{\prime} 58.0^{\prime}$ 'E, - 7.291377, 111.999448 atau secara kasat mata bahwa Desa Geger terletak sebelah Timur Laut dari pusat Kota Bojonegoro Jawa Timur. Desa Geger memiliki beberapa dukuhan, diantaranya ada desa Geger Krajan (sebagai pusat desa), dusun Kawis, dukuh Brangwetan, dusun templek, dan dusun Kalitengah.

Sebagai desa perbatasan inilah, Desa Geger memiliki berbagai keanekaragaman, mulai dari sikap berpikir, matapencaharian, kegiatan sosial, keorganisasian, dan pendidikan. Pendidikan di desa Geger sudah memiliki jenis pendidikan formal dan nonformal. Meskipun berada di perbatasan, desa ini dapat dikatakan sebagai desa yang memiliki pendidikan formal dengan jenjang sekolah lengkap sesuai amanat pemerintah wajib belajar 12 tahun. Jenjang pendidikan ini mulai dari PP (pos paud), SD, SMP, dan SMA.

Berdasarkan hasil wawancara pada hari Kamis, 08 Agustus 2019 dengan kepala desa Geger, bapak Kamijo. Beliau menjelaskan bahwa desa Geger merupakan desa yang memiliki pendidikan terlengkap di banding dengan desa sekitarnya, bahkan dengan desa lain yang ada di Kecamatan Kedungadem. Ada pun data sekolah yang ada di desa Geger antara lain 1) Pos paud (PP) Puring I Geger, 2) Pos paud (PP) Puring II Geger, 3) KB Aisyiyah Geger, 4) KB Sunan Drajat, 5) TK ABA Geger, 6) TK Dharma Wanita Geger, 7) TK Sunan Drajat, 8) MI Muhammadiyah 27 Geger, 9) MI Sunan Drajat, 10) SDN Geger, 11) MTs. Sunan Drajat, dan 12) MA Sunan Drajat. Adapun data pendidikan nonformal yang ada di desa Geger antara lain, 1) TPA Al Kautsar, 2) TPA Al Karim, 3) TPA At Taqwa, 4) TPA Al Amin, 5) TPA Al Muttaqin, dan 6) TPQ Sunan Kalijaga (Catatan Lapangan Hasil Wawancara, 2019).

Kegiatan pembelajaran di berbagai sekolah di desa Geger dapat dilihat pada foto berikut.

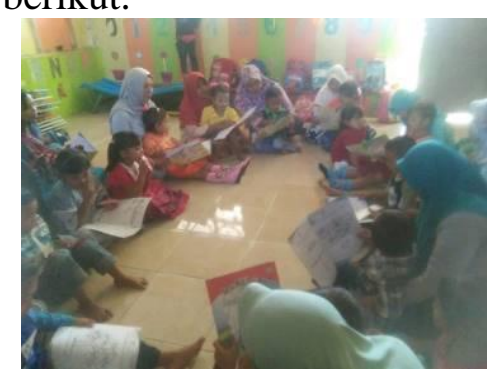

Gambar 1. Kegiatan pembelajaran di TK ABA Geger

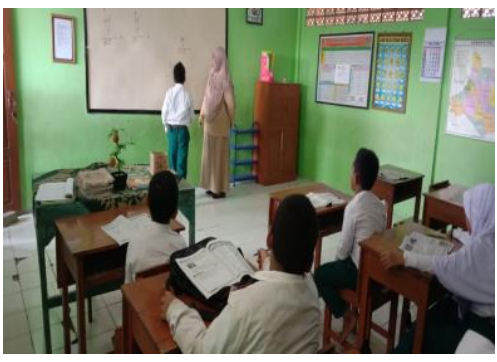

Gambar 2. Kegiatan pembelajaran di MI Muhammmadiyah 27 Geger

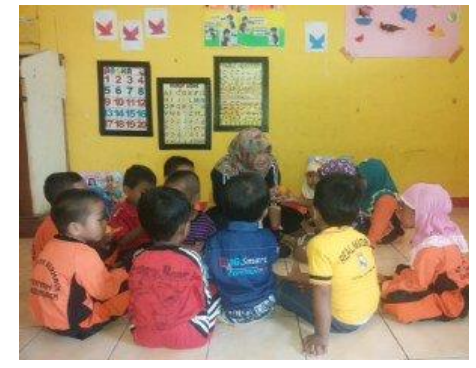

Gambar 3. Kegiatan pembelajaran di KB Aisyiyah Geger

Melihat foto-foto kegiatan pembelajaran di sekolah-sekolah yang ada di desa Geger, maka, dapat disimpulan bahwa proses pembelajaran masih terfokus menggunakan media buku. Berdasarkan tuturan salah satu kepala sekolah di desa Geger, yaitu bapak Jumari, S.Pd., kepala sekolah MI Muhammadiyah 27 Geger menuturkan bahwa guruguru di sekolahnya belum menggunakan media pembelajaran 3 dimensi dalam mengajar karena belum bisa membuat media pembelajaran 3D. Berdasarkan tuturan bapak Agus 
Priyanto, S.Pd., guru di SDN Geger bahwa guru-guru di SDN Geger sangat antusias jika mendapatkan pelatihan membuat media pembelajaran, terkhusus media pembelajaran 3D.

Informasi terakhir yang pengabdi dapatkan adalah bersumber dari ibu Anis Siati, S.Pd., guru TK ABA Geger, ibu Anis Siati, S.Pd. menuturkan bahwa ibu Anis Siati, S.Pd. belum pernah menggunakan media pembelajaran 3D saat mengajar. Saat pengabdi menunjukkan contoh media pembelajaran 3D pop-up, ibu Anis Siati, S.Pd. menjawab, bahwa beliau tahu itu adalah media pembelajaran namun tidak tahu namanya jika itu adalah pop-up, ibu Anis Siati, S.Pd. menuturkan bahwa saat ibu Anis Siati, S.Pd. berkunjung di toko buku di kota Bojonegoro, ibu Anis Siati, S.Pd. juga melihat media serupa pop-up dan harganya sangat mahal. Untuk level TK ABA Geger, media pop-up belum terjangkau.

Melihat hasil analisis situasi pada mitra pengabdian. Secara spesifik teridentifikasi bahwa mitra pengabdian memiliki permasalahan utama yang dihadapi, yaitu, 1) Guruguru di desa perbatasan belum memiliki pengetahuan tentang media pembelajaran 3D sehingga guru-guru di desa perbatasan belum bisa membuat media pembelajaran 3D, 2) Guru-guru di desa perbatasan belum memiliki keterampilan melakukan inovasi pembelajaran melalui media pembelajaran 3D, 3) Guru-guru di desa perbatasan belum pernah menggunakan media pembelajaran pop-up dan movable book saat pembelajaran di kelas, 4) Guru-guru di desa perbatasan belum memiliki keahlian dan keterampilan dalam membuat media pembelajaran 3D melalui pop-up dan movable book, 5) Minimnya sosialisasi dan workshop membuat media pembelajaran 3D, 6) Mahalnya harga media pembelajaran 3D

Permasalahan yang dihadapi oleh mitra selanjutnya dianalisis dengan SWOT. Hasil analisis permasalahan dengan SWOT dapat dilihat pada gambar berikut,

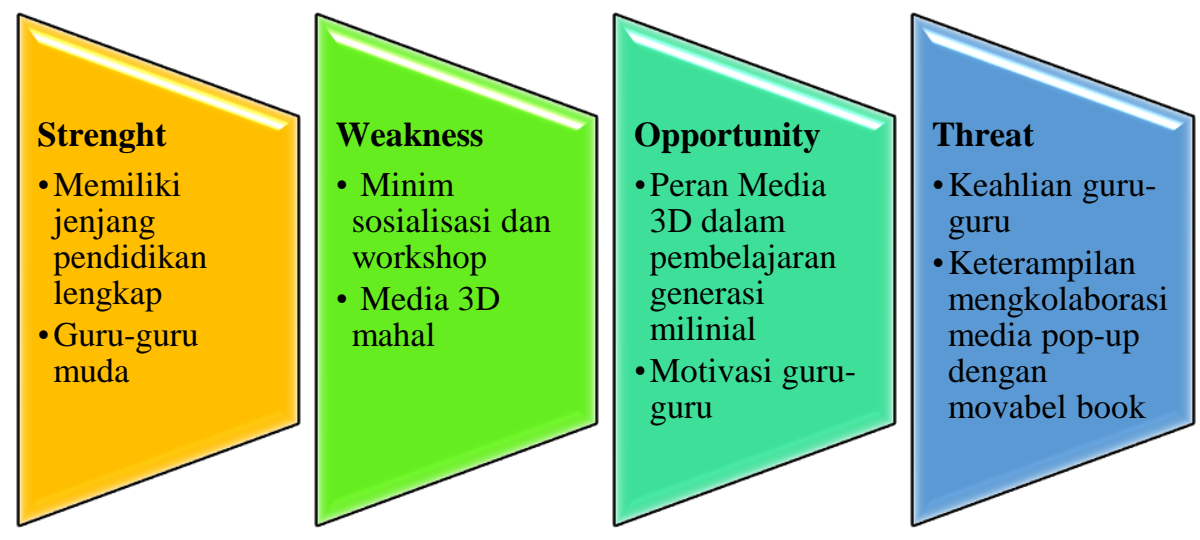

Gambar 4 Analisis SWOT

Strength (kekuatan), Desa Geger memiliki jenjang pendidikan lengkap mulai dari PP (pos paud), SD, SMP, dan SMA, kelengkapan jenjang ini menjadikan desa Geger memiliki siswa yang berasal dari desa-desa tetangga yang berada pada kecamatan yang berbeda. Selain itu, pengajarnya pun juga ada yang berasal dari luar desa Geger. Pengajar di desa Geger dapat dikatakan masih muda-muda, banyak guru-guru di sana lulusan sarjana di atas tahun 2010. Hal ini dapat dikatakan bahwa keilmuaan yang dimiliki sangatlah mudah dalam menerima pelatihan pengabdian. Jenjang pendidikan yang lengkap dan guru yang muda akan memberikan banyak sumbangsih dan inovasi dalam membuat media pembelajaran 3D, sehingga kedua hal ini dapat dijadikan sebagai kekuatan (strength) dalam melaksanakan pengabdian di desa perbatasan ini. 
Weakness (kelemahan), Jenjang pendidikan mulai dari PP (pos paud), SD, SMP, dan SMA di desa perbatasan ini belum pernah mendapatkan sosialisasi dan workshop membuat media pembelajaran 3D sehingga mitra harus diberikan materi dan petunjuk pembuatan media pembelajaran 3D dengan waktu yang cukup lama. Selain itu, mahalnya media pop-up tidak dapat dijangkau oleh semua sekolah di desa ini yang mengakibatkan guru belum pernah menggunakan media pembelajaran 3D saat mengajar.

Opportunity (peluang), Peran media merupakan kompenen dalam pembelajaran yang harus ada pada saat proses pembelajaran berlangsung, terlebih media 3D yang sangat tepat diterapkan pada generasi milinial. Media ini mampu meningkatkan motivasi peserta didik dalam mengikuti pembelajaran dibanding dengan media pembelajaran visual 2D atau yang lainnya. Peran ini ditambah dengan adanya motivasi guru-guru sehingga pembuatan kolaborasi media pop-up dan movable book dalam menghasilka media pembelajaran 3D akan berjalan sesuai dengan tujuan pengabdian.

Threat (Ancaman), Guru-guru di desa perbatasan memiliki keahlian yang berbedabeda, keahlian yang berbeda inilah menjadikan keterampilan yang dimiliki juga berbeda pula sehingga dapat dimungkinkan konsep pembuatan media pembelajaran 3D tidak sesuai dengan kriteria pop-up dan movable book yang bagus. Kedua hal ini merupakan sebuah ancaman bagi keberhasilan pengabdian ini.

Berdasarkan hasil analisis SWOT (Strength, Weakness, Opportunity, dan Threat) maka tim pengabdi memberikan solusi permasalahan sesuai pembelajaran pada generasi milenial yaitu pemberian pelatihan membuat media pembelajaran 3D melalui koloborasi media pop-up dan movable book.

Pada abad ke-19 Puleo (2011) menyebutkan pop-up mulai banyak dibuat untuk tujuan pembelajaran dan pengajaran moral. Penelitian Van-Dyk \& Hewitt (2011) menyebutkan sejarah tentang pop-up dimulai pada abad medival monastery atau sekitar abad pertengahan. Buku-buku yang berisi tentang pop-up berisi tentang catatan, informasi dan juga hitungan data.

Barton (2005) menjelaskan bahwa pop-up memiliki gerakan otomatis saat dibuka. Kelebihan pop-up adalah visualisasi gambar berdimensi yang mampu bergerak dan berubah bentuk (Hardjo, Retnowati, \& Rostikawati (2017) sehingga memberi kesan tersendiri bagi anak untuk semangat belajar (Putri, Yasbiati, \& Pranata (2018). Pop-up dapat dibuat dengan menyiapkan alat tulis, alat penimbul kertas (Gregory, 2016), kartu, lem, gunting (Birmingham, 2010), karet gelang, kancing, tali, pita, kain bulu, dan bungkus kado (alat dekorasi) (Irvine, 2008).

Hasanudin, dkk. (2018a) memberikan langkah-langkah dalam membuat pop-up. Langkah pertama adalah mentulis cerita pendek, langkah kedua adalah mencetak gambar yang telah dibuat, langkah ketiga adalah menyiapkan kertas karton atau jenis lain yang cukup tebal. Kertas ini akan menjadi halaman buku, langkah keempat adalah memotong kertas tersebut sesuai selera. Untuk awalan, potong seukuran setengah halaman A4, langkah kelima adalah melipat kertas menjadi dua, langkah keenam adalah mengunting sepanjang $1 \mathrm{~cm}$ di punggung kertas (bagian lipatan). Sediakan jarak 0,5 cm kemudian gunting lagi, langkah ketujuh adalah membuka lipatan kertas, kemudian tekan bagian yang digunting ke dalam hingga menonjol. Anda akan menempelkan gambar-gambar yang telah dibuat sebelumnya di bagian ini, langkah kedelapan adalah posisikan kertas secara melintang (landscape), langkah kesembilan adalah menempelkan gambar yang telah dicetak ke bagian dalam kertas yang menonjol, langkah kesepulah adalah ulangilah langkah ketujuh dan kedepalan sesuai kebutuhan. Anda dapat mengatur posisi tonjolan tempat gambar dengan menambah/mengurangi panjang guntingan, langkah kesebelas 
adalah menulis cerita di bagian bawah gambar. Lengkapi pula halaman dengan ilustrasi lain di sekitar gambar, langkah kedua belas adalah menyatukan halaman-halaman dengan menggunakan lem. Untuk memastikan halaman pop-up book dapat dibuka dengan mudah, bagian lipatan buku tidak perlu dilem, langkah ketiga belas adalah menulis judul buku di sampul depan dan pop-up book pun telah jadi.

Semakin hari, pop-up banyak digunakan dan dikenal oleh orang-orang baik sebagai ilustrasi dari sebuah cerita yang dipadupadankan dengan teks cerita atau sebagai objek tanpa teks seperti untuk memadupadankan warna lukisan, mengidentifikasi jenis burung, menghitung angka pernikahan, dan hadiah untuk anak-anak. Bentuk padu padan inilah, memungkinkan pop-up berkolaborasi dengan movable book.

Movable book pertama diterbitkan dalam jumlah besar adalah yang diproduksi oleh Dean \& Son, sebuah perusahaan penerbitan yang didirikan di London sebelum 1800. Pada tahun 1860-an perusahaan mengklaim sebagai "pencetus movable book anak-anak di mana karakter dapat dibuat untuk bergerak dan bertindak sesuai dengan insiden yang dijelaskan dalam setiap cerita. " Dari pertengahan abad ke-19, Dean mengalihkan perhatiannya ke produksi buku bergerak dan antara tahun 1860-an dan 1900 mereka menghasilkan sekitar lima puluh judul (Montanaro \& Ann, 1996). Penelitian Syafutri \& Soeharto (2019) menjelaskan bahwa movable book layak dan efektif digunakan sebagai suplemen pembelajaran untuk meningkatkan keterampilan proses sains siswa. Abrahamson (1982) menjelaskan bahwa buku pop-up dan movable book memberikan rangsangan untuk menulis tulisan yang kreatif dan asli.

Pengkolaborasian kedua media ini nantinya akan memberikan sebuah konsep media pembelajaran 3D yang sangat menarik dan dapat menumbuhkan minat siswa dalam mengikuti pembelajaran di kelas. Hasil penelitian yang dilakukan oleh Yuliati, Suhartiningsih, \& Hidayati (2017) menunjukkan bahwa minat baca dan kemampuan bahasa siswa dapat meningkat ketika diajar dengan media. Oleh karena itu, Pelatihan ini dilakukan secara intensif agar guru-guru di Desa Geger memiliki pengetahuan dan keterampilan dalam membuat media pembelajaran 3D melalui kolaborasi pop-up dan movable book.

\section{METODE PELAKSANAAN}

Pelaksanaan pelatihan ini dimulai dari tanggal 04 Juli hingga 08 Agustus 2020. Pelaksanaan pelatihan terbagi menjadi dua konsep, yaitu tatap muka dan daring. Pelatihan dalam bentuk tatap muka dilakukan untuk kegiatan briefing dan pemberian paket pelatihan. Kegiatan ini dilakukan pada hari Sabtu, 04 Juli 2020 dan dibagi menjadi dua sesi. Sesi pertama diikuti oleh KB Sunan Drajat, RA Sunan Drajat, MI Sunan Drajat, KB Aisyiyah, MI Muhammadiyah 27 Geger, TPA Al Karim, dan TPA Al Kautsar sedang sesi kedua diikuti oleh Pos Paud Puring I, Pos Paud Puring II, TK ABA Geger, TK Dharma Wanita, SDN Geger, MTs. Sunan Drajat, dan MA Sunan Drajat. Kegiatan lain yang dilakukan dalam bentuk tatap muka adalah pada saat penutupan. Jumlah mitra pengabdian pada masing-masing sesi dapat dilihat pada tabel berikut.

Tabel 1 Daftar Mitra pengabdian

\begin{tabular}{|c|c|c|}
\hline Sesi & Peserta & Jumlah \\
\hline 1 & $\begin{array}{ll}- & \text { KB Sunan Drajat } \\
- & \text { RA Sunan Drajat }\end{array}$ & $\begin{array}{ll}- & 1 \\
- & 1\end{array}$ \\
\hline
\end{tabular}




\begin{tabular}{|c|c|c|}
\hline Sesi & Peserta & Jumlah \\
\hline & - MI Sunan Drajat & -3 \\
\hline & - KB Aisyiyah & -1 \\
\hline & - MIM 27 Geger & -9 \\
\hline & - TPA Al Karim & -1 \\
\hline & - TPA Al Kautsar & \\
\hline \multirow{7}{*}{2} & - $\quad$ Pos Paud Puring I & -1 \\
\hline & - $\quad$ Pos Paud Puring II & -1 \\
\hline & - TK ABA Geger & -2 \\
\hline & - $\quad$ TK Dharma Wanita & -2 \\
\hline & - SDN Geger & -2 \\
\hline & - MTs. Sunan Drajat & -5 \\
\hline & - MA Sunan Drajat & -6 \\
\hline
\end{tabular}

Pelatihan dalam bentuk daring dilakukan dengan menggunakan aplikasi zoom. Alasan pemilihan aplikasi zoom karena sangat mudah digunakan saat presentasi materi dan merekam kegiatan dalam bentuk mp4 sehingga memudahkan mitra untuk menonton ulang materi yang disampaikan oleh tim pengabdi melalui chanel youtube. Hal ini diperkuat oleh Hidayatullah, dkk. (2020) bahwa zoom mudah digunakan dan mampu merekam video, suara, dan paparan materi. Brahma (2020) memaparkan bahwa dengan menggunakan zoom pada saat meeting, keamaan rekaman lebih terjaga. Pengguna zoom harus memastikan jaringan internet dengan baik (Zubaidah, Putra, \& Gade, 2020).

Materi dalam bentuk daring meliputi 1) pelatihan pengoperasian aplikasi momentcam dilakukan pada hari Senin, 06 Juli 2020, 2) pelatihan pengoperasian aplikasi ibisPaint X dilakukan pada hari Kamis, 09 Juli 2020, 3) pelatihan pengoperasian aplikasi invinite design dilakukan pada hari Sabtu, 11 Juli 2020, 4) pelatihan Menyusun pop-up dan movable book dilakukan pada hari Senin, 13 Juli 2020, 5) monitoring produk yang dihasilkan oleh mitra dilakukan pada hari Senin 27 Juli 2020.

Pelaksanaan pelatihan ini dibagi menjadi tiga tahapan utama, yaitu tahap awal, tahap inti, dan tahap akhir, Adapun ketiga tahap ini dapat dijelaskan pada gambar berikut.

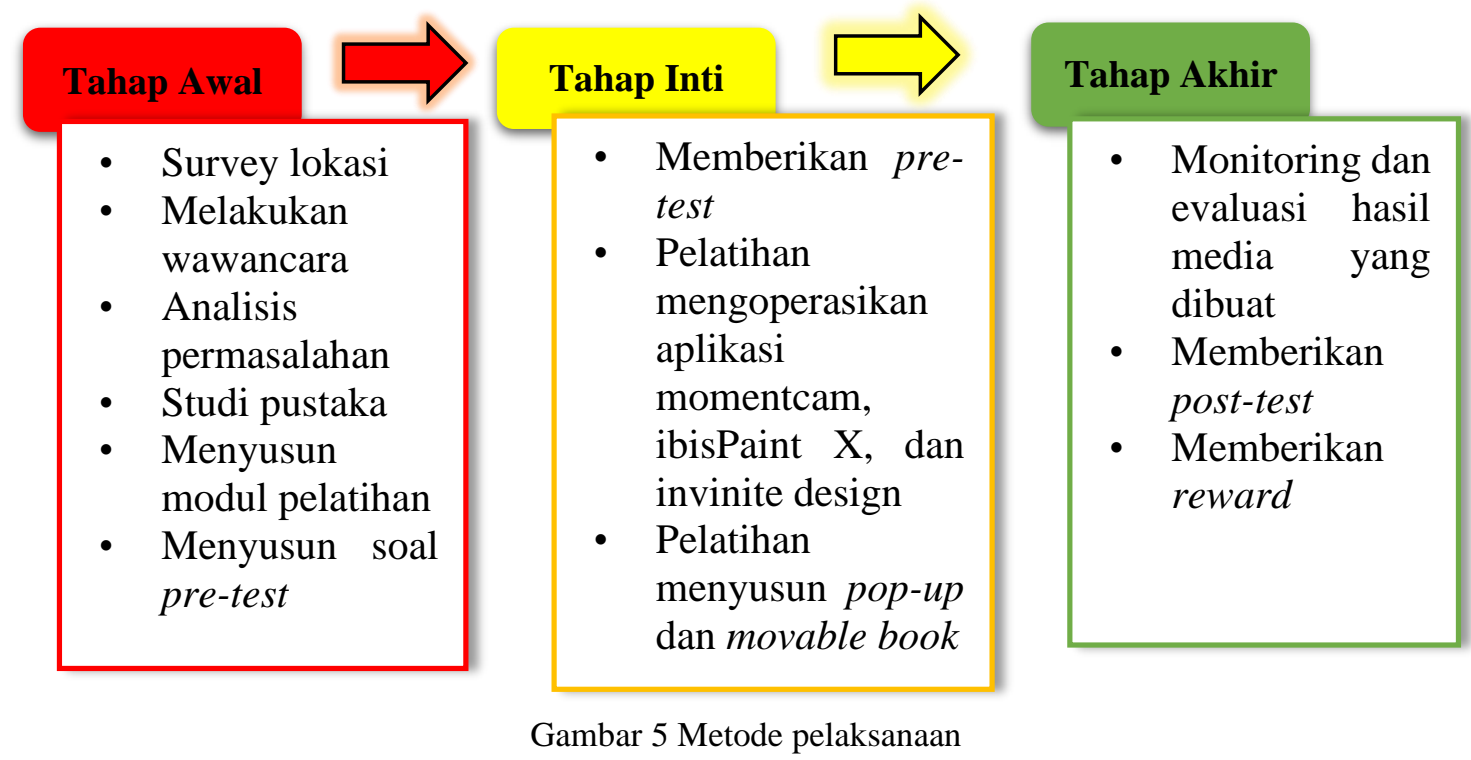


Ketiga tahapan ini berfungsi untuk mengukur pengetahuan dan keterampilan mitra pengabdian tentang media pembelajaran 3D. Kedua hal ini menjadi tujuan akhir dari pelaksanaan program Pengabdian kepada Mayarakat. Pengetahuan dan keterampilan mitra diukur dengan cara membandingkan hasil pretes dan postes seluruh mitra pengabdian. Dari hasil perbandingan inilah akan diketahui seberapa besar peningkatan pengetahuan dan keterampilan mitra tentang media pembelajaran 3D baik peningkatan secara individu atau secara keseluruhan.

Soal pengetahuan dan keterampilan masing-masing terdiri dari 10 soal. Kisi-kisi soal tersebut dapat dilihat pada tabel berikut

Tabel 2 Kisi-kisi soal

\begin{tabular}{|c|c|c|}
\hline No. & $\begin{array}{l}\text { Soal Pengetahuan } \\
\text { (SP) }\end{array}$ & $\begin{array}{l}\text { Soal Keterampilan } \\
\text { (SK) }\end{array}$ \\
\hline 1 & Mengetahui arti media & Dapat membuat media 3D \\
\hline 2 & Mengetahui arti media 2D & Dapat membuat pop-up \\
\hline 3 & Mengetahui pengertian pop-up & Dapat membuat movable book \\
\hline 4 & Mengetahui pengertian movable book & Dapat menerapkan teknik lift the flap \\
\hline 5 & $\begin{array}{l}\text { Mengetahui teknik lift the flap dari sebuah } \\
\text { gambar }\end{array}$ & $\begin{array}{l}\text { Dapat menerapkan teknik parallel slide } \\
\text { mechanism }\end{array}$ \\
\hline 6 & Mengetahui teknik parallel slide mechanism & Dapat menerapkan teknik v-fold mechanism \\
\hline 7 & Mengetahui logo ibisPaint X & $\begin{array}{l}\text { Dapat menerapkan teknik internal stand } \\
\text { mechanism }\end{array}$ \\
\hline 8 & $\begin{array}{l}\text { Mengetahui susunan teknik media pembelajaran } \\
\text { 3D }\end{array}$ & $\begin{array}{l}\text { Dapat mengoperasikan aplikasi ibisPaint } \mathrm{X} \text {, } \\
\text { momentcam, atau aplikasi sejenis }\end{array}$ \\
\hline 9 & $\begin{array}{l}\text { Mengetahui syarat (hal yang harus diperhatikan) } \\
\text { dalam teknik menyusun desain media } \\
\text { pembelajaran 3D }\end{array}$ & $\begin{array}{l}\text { Dapat menggunakan kolaborasi pop-up dan } \\
\text { movable book dalam menyusun media } \\
\text { pembelajaran 3D }\end{array}$ \\
\hline 10 & 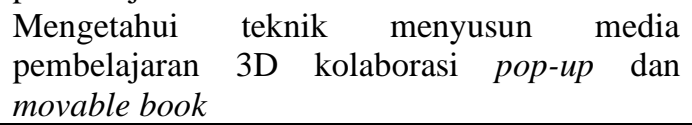 & $\begin{array}{l}\text { Dapat menuangkan ide ke dalam bentuk } \\
\text { media pembelajaran 3D }\end{array}$ \\
\hline
\end{tabular}

Soal tentang pengetahuan dan keterampilan terlebih dahulu sudah divalidasi oleh tiga orang validator, yaitu ibu Heny Kusuma Widyaningrum dari Universitas PGRI Madiun, ibu Rumi Prasetyaningrum dari SMK Bhina Karya Karanganyar, dan bapak Abdul Rahim Arman Putera Dapubeang dari Universitas Negeri Timor. Ketiga validator telah mereview dan merevisi kedua puluh soal tersebut dengan simpulan akhir bahwa soal-soal tersebut layak digunakan untuk pretes dan postes mitra pengabdian.

Setelah ketiga tahap dilaksanakan. Pengabdi melakukan FGD dengan mitra pengabdian, pembantu peneliti, dan pembantu lapangan untuk merumuskan hasil yang dicapai dalam melaksanakan pengabdian ini.

\section{HASIL DAN PEMBAHASAN}

\section{Pengetahuan Mitra Pengabdian tentang Media Pembelajaran 3D}

Pengetahuan awal guru-guru di Desa Geger Kecamatan Kedungadem Kabupaten Bojonegoro tentang media pembelajaran 3D dapat dilihat dari rekap jawaban seperti gambar berikut. 


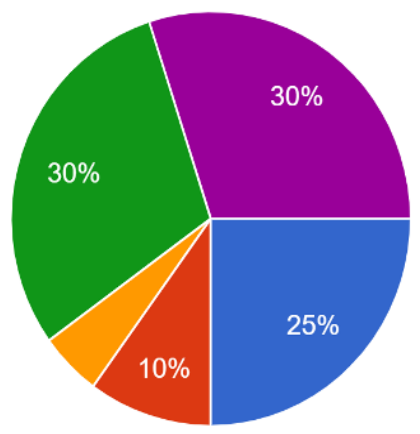

media tanpa proyeksi yang penyajiannya secara visual dimensional

dapat yang dapat diraba sehingga membantu mewujudkan realitas

syaratnya harus cukup besar dan jelas, menggunakan benda yang aman, dapat diintegrasikan dengan media yang lain, disimpan dan tidak perlu dipajang

jawaban a, b, dan c benar

jawaban a, b, dan c salah

Gambar 6 Rekap jawaban soal ke-2 mitra pengabdian

Gambar di atas merupakan rekap jawaban mitra dari salah satu soal yang diberikan. Soal dari rekap jawaban di atas merupakan soal untuk mengukur pengetahuan tentang media 3D. Tim pengabdi membuat pertanyaan tentang media 2D dan pilihan jawaban mengarah pada pengertian media 3D. Berdasarkan soal yang diberikan, hanya 30\% mitra menjawab benar dan $70 \%$ mitra menjawab pilihan salah. Pilihan jawaban e (warna ungu) merupakan pilihan jawaban benar. Berdasarkan jawaban mitra tersebut, maka dapat disimpulkan bahwa mitra pengabdian masih memiliki pengetahuan yang kurang tentang media 3D karena hanya ada 30\% mitra yang memiliki pengetahuan tentang media 3D dari keseluruhan mitra yang hadir dalam acara briefing.

Untuk meningkatkan pengetahuan mitra, maka tim pengabdian membuat FGD untuk merumuskan dan membuat rencana pelatihan. Rumusan yang dihasilkan dari hasil FGD adalah memberikan materi tentang 1) teknik menuangkan ide 2) mengenalkan beberapa aplikasi pembuat karakter kartun (momentcam, ibispaint x, dan invinite design), dan 3) mengenalkan teknik-teknik dalam membuat media 3D (Ryan, 2002). Rencana pelatihan dari hasil FGD adalah menyepakati untuk memberikan tutorial secara tatap muka dan daring. Tutorial tatap muka dilakukan untuk kegiatan briefing, pembagian paket pelatihan, dan unjuk kerja produk (pada saat penutupan), sedangkan tutorial daring dilakukan untuk kegiatan menyampaian materi dengan menggunakan aplikasi zoom sehingga mitra harus memiliki hp android atau leptop. Fitrianingsih, dkk. (2020) menyebutkan kepemilikan hp atau leptop bagi guru sangat mempermudah pengaplikasian kelas daring. Tutorial daring atau pun tatap muka dapat ditunjukkan pada gambar berikut.

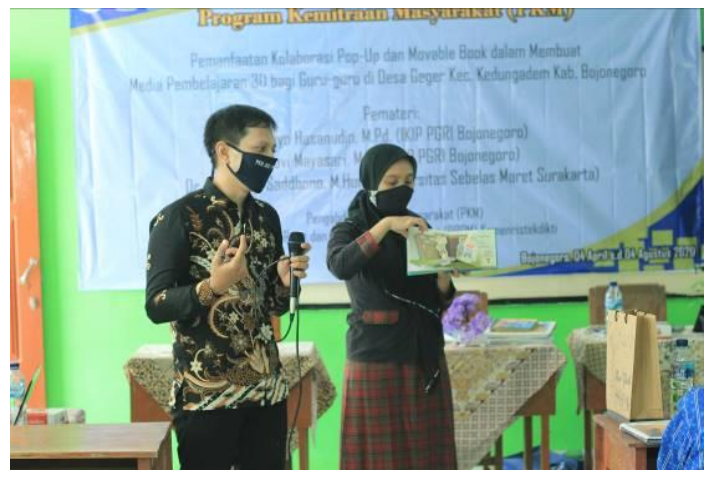

Gambar 7 Tutorial tatap muka

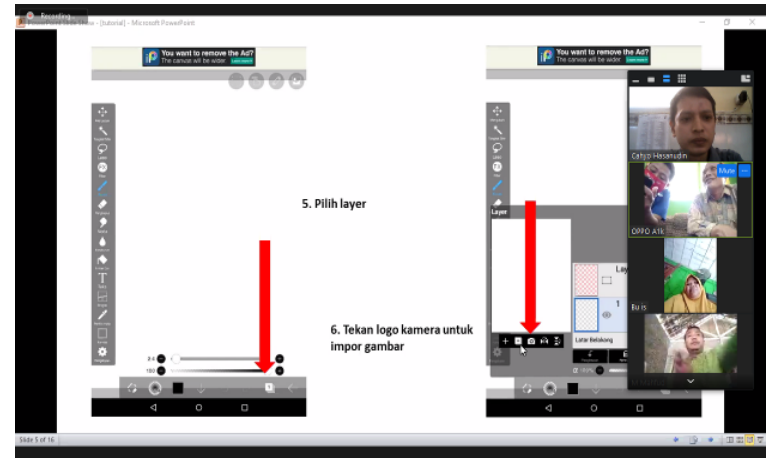

Gambar 8 Tutorial daring menggunakan aplikasi zoom 
Setelah pemberian tutorial secara tatap muka dan daring. Tim pengabdi memberikan soal postes kepada mitra pengabdian. Hasil postes dapat dilihat pada gambar berikut.

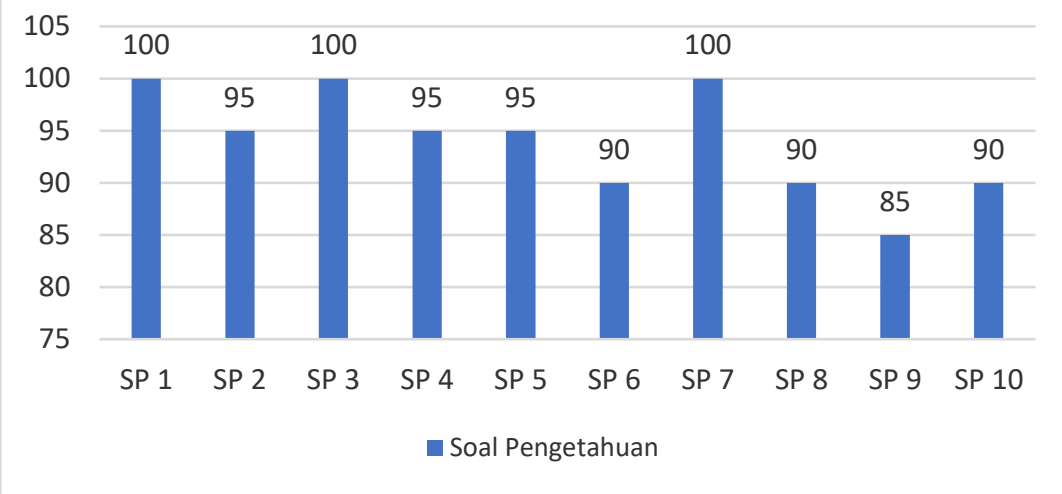

Gambar 9 Hasil postes pengetahuan tentang media 3D

Hasil postes selanjutnya dibandingkan dengan hasil pretes. Pembandingan kedua hasil ini bertujuan untuk mengetahui peningkatan pengetahuan mitra pengabdian tentang media pembelajaran 3D. Hasil tersebut dapat dilihat pada gambar berikut ini.

\section{Perbandingan hasil pretes dan postes}

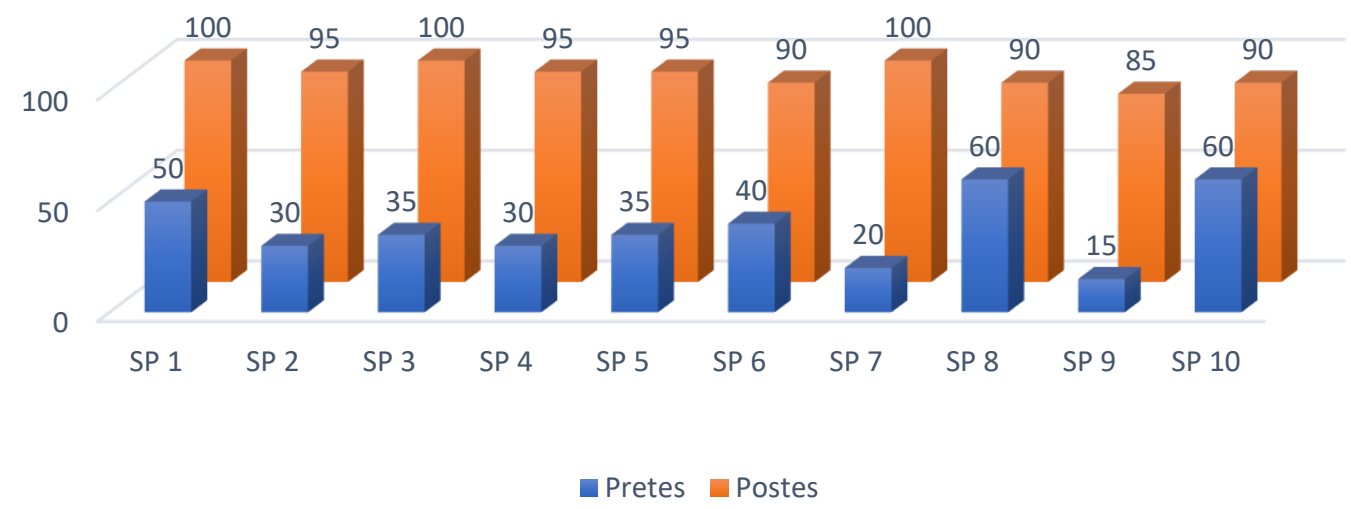

Gambar 10 Perbandingan hasil pretes dan postes pengetahuan tentang media pembelajaran 3D

Berdasarkan hasil perbandingan pretes dan postes di atas, dapat diketahui bahwa rerata hasil pretes sebesar 38\% dan rerata hasil postes sebesar 94\%, maka dapat diketahui terdapat peningkatan sebesar 57\%. Hal ini dapat disimpulkan bahwa ada peningkatan pengetahuan tentang media pembelajaran 3D sebesar 57\% setelah mitra pengabdian (guru-guru di Desa Geger Kecamatan Kedungadem Kabupaten Bojonegoro mendapat pelatihan pembuatan media pembelajaran 3D. Simpulan ini diperkuat oleh hasil angket dari salah satu guru RA Sunan Drajat, ibu Anis Musyayaroh, S.Pd. dengan pertanyaan "Pengetahuan apa sajakah yang sudah didapatkan setelah mengikuti pelatihan?" ibu Anis menjawab pelatihan ini memberikan ilmu dan pengetahuan baru penggunaan aplikasiaplikasi penghasil karakter kartun sehingga mempermudah dalam menyusun media pembelajaran 3D. Hal ini dapat dilihat pada lembar angket berikut. 


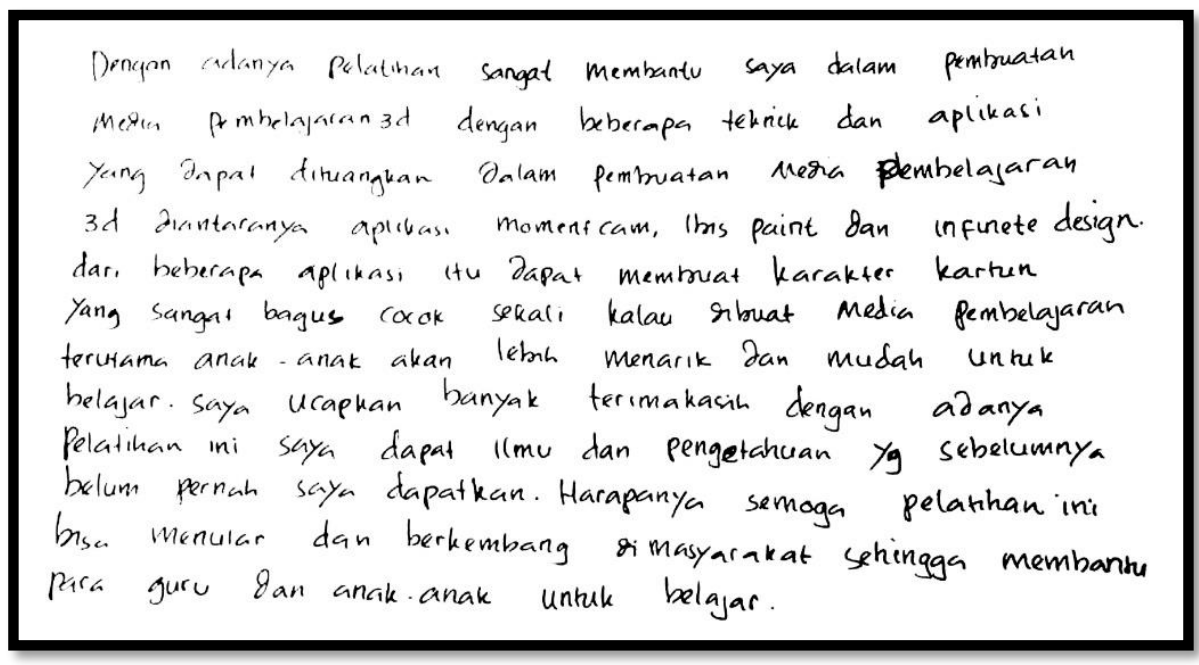

Gambar 11 Hasil angket pengetahuan tentang media pembelajaran 3D

Hasil pengabdian Shofiyah \& Wulandari (2017) menunjukkan bahwa adanya peningkatan pemahaman guru (mitra pengabdian) setelah diberikan pelatihan dan workshop tentang pop-up up book. Hal ini dapat dikatakan bahwa hasil pengabdian yang pernah dilakukan oleh Shofiyah \& Wulandari dengan pengabdi yaitu sama-sama menghasilkan peningkatan pengetahuan guru.

\section{Keterampilan Mitra Pengabdian dalam Membuat Media Pembelajaran 3D}

Keterampilan awal guru-guru di Desa Geger Kecamatan Kedungadem Kabupaten Bojonegoro tentang media pembelajaran 3D dapat dilihat dari rekap jawaban seperti gambar berikut.

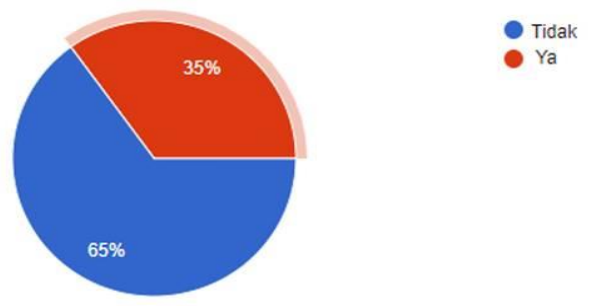

Gambar 12 Keterampilan awal mitra pengabdian

Gambar di atas merupakan rekap jawaban dari soal nomor satu dengan pernyataan soal “Apakah bapak/ibu bisa membuat media 3D?". Berdasarkan rekap jawaban dari gambar tersebut dapat disimpulkan bahwa keterampilan awal yang dimiliki oleh guruguru di Desa Geger tentang keterampilan dalam membuat media 3D masih kurang. Hal ini dapat dibuktikan dengan jumlah mitra yang menjawab "ya" lebih sedikit dibanding yang menjawab "tidak". Hanya ada 35\% mitra yang bisa membuat media 3D dari total mitra yang mengikuti kegiatan briefing.

Setelah mengetahui keterampilan mitra dalam membuat media 3D masih kurang, maka tim pengabdi memberikan tutorial dalam membuat media 3D. Tutorial tersebut mencakup 1) praktik mengonsep ide media 3D yang akan dibuat, 2) praktik instalasi dan pengoperasian aplikasi momentcam, ibispaint x, dan invinite design, 3) praktik teknikteknik membuat media pop-up up dan movable book, seperti teknik teknik v-fold mechanism, internal stand mechanism, rotary mechanism, mouth, parallel slide 
mechanism, lift the flap, dan pull tab, dan 4) praktik mengkolaborasi pop-up dan movable book.

Praktik membuat teknik-teknik pada pop-up dilakukan secara tatap muka pada saat briefing sedangkan praktik-praktik yang lain dilakukan secara daring. Praktik yang dilakukan secara daring yaitu praktik instalasi dan pengoperasian aplikasi momentcam, ibispaint $\mathrm{x}$, dan infinite design. Berdasarkan hasil observasi setelah pelaksanaan tutorial daring, mitra sudah berhasil mengimplmentasikan aplikasi-aplikasi tersebut. Karakter kartun yang dihasilkan oleh mitra dapat dilihat pada gambar berikut.

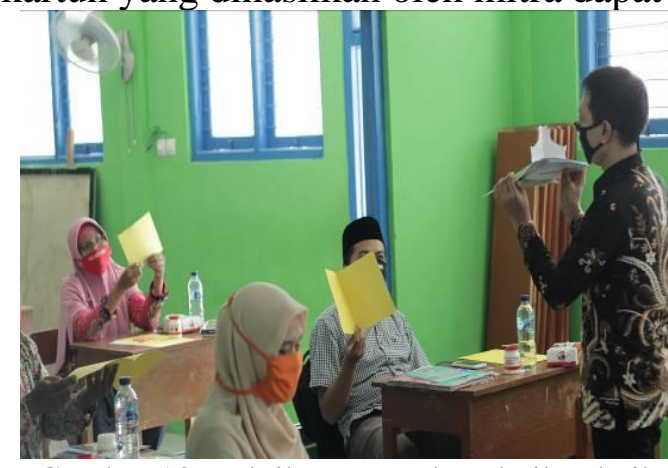

Gambar 13 Praktik tatap muka teknik-teknik pada pop-up

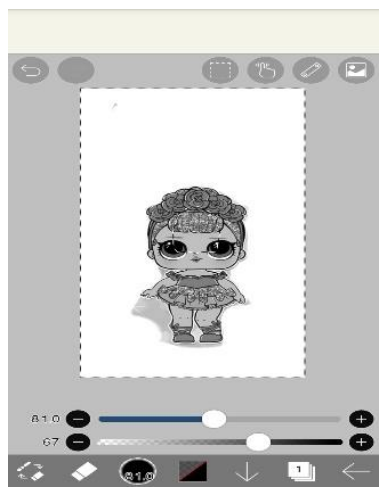

Gambar 15 Praktik daring dengn hasil karakter kartun dari aplikasi ibisPaint X

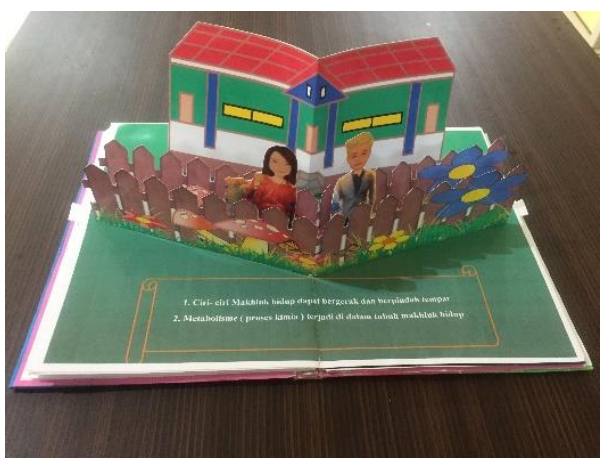

Gambar 17 Media 3D yang sudah dibuat oleh mitra 1
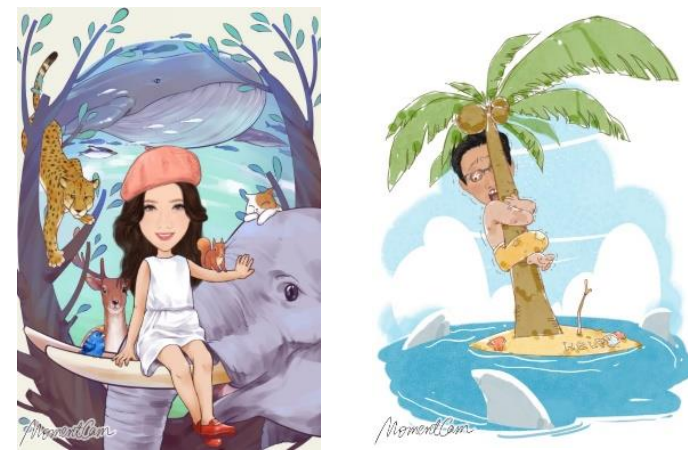

Gambar 14 Praktik daring dengn hasil karakter kartun dari aplikasi momentcam
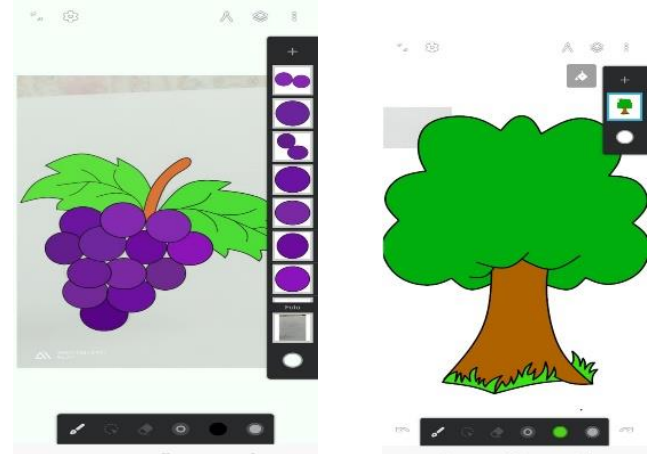

Gambar 16 Praktik daring dengn hasil karakter kartun dari aplikasi infinite design

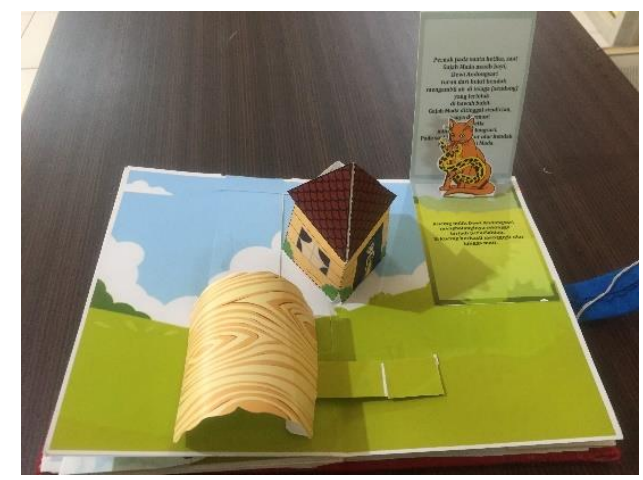

Gambar 18 Media 3D yang sudah dibuat oleh mitra 2

Setelah pemberian tutorial secara tatap muka dan daring. Tim pengabdi memberikan soal postes kepada mitra pengabdian. Hasil postes menunjukkan bahwa 


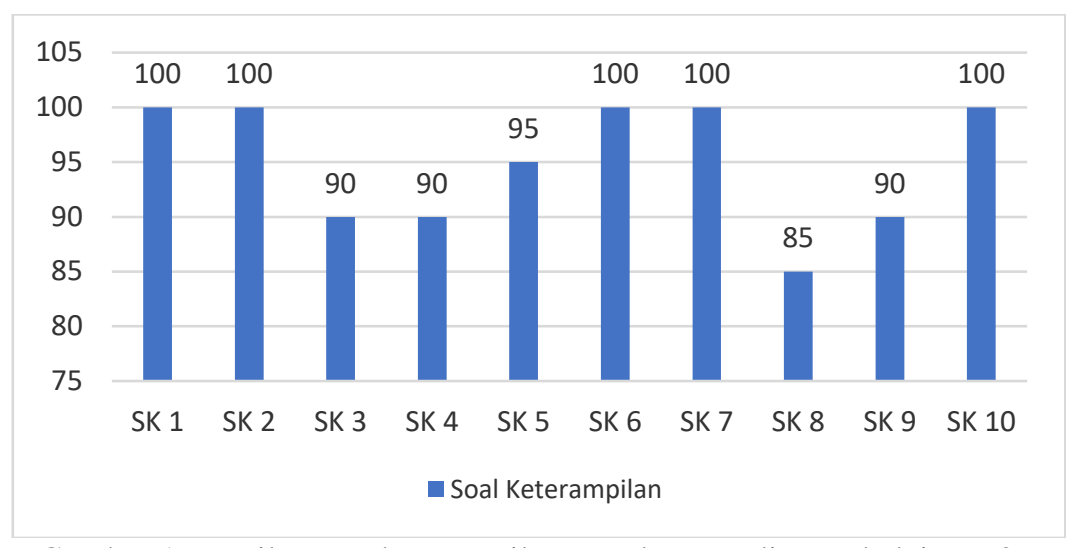

Gambar 19 Hasil postes keterampilan membuat media pembelajaran 3D

Hasil postes selanjutnya dibandingkan dengan hasil pretes. Pembandingan kedua hasil ini bertujuan untuk mengetahui peningkatan keterampilan mitra pengabdian dalam membuat media pembelajaran 3D. Hasil tersebut dapat dilihat pada gambar berikut ini.

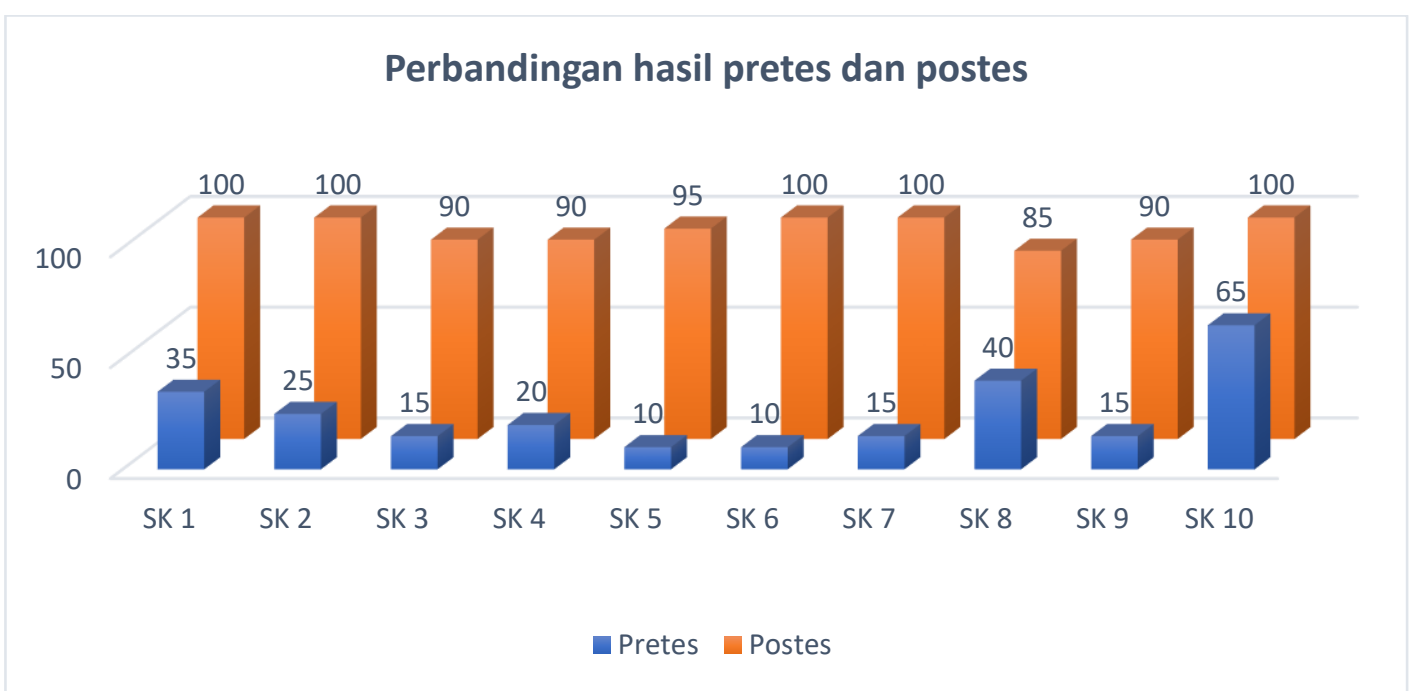

Gambar 20 Perbandingan hasil pretes dan postes keterampilan dalam membuat media pembelajran 3D

Berdasarkan hasil perbandingan pretes dan postes di atas, dapat diketahui bahwa rerata hasil pretes sebesar $25 \%$ dan rerata hasil postes sebesar $95 \%$, maka dapat diketahui terdapat peningkatan sebesar $70 \%$. Hal ini dapat disimpulkan bahwa ada peningkatan keterampilan dalam membuat media pembelajaran 3D sebesar $70 \%$ setelah mitra pengabdian (guru-guru di Desa Geger Kecamatan Kedungadem Kabupaten Bojonegoro mendapat pelatihan pembuatan media pembelajaran 3D. Simpulan ini diperkuat oleh hasil angket dari salah satu guru MA Sunan Drajat, ibu Sholihah Al Aminiyah, S.Pd. dengan pertanyaan "Setelah mengikuti pelatihan, mengapa ibu bisa membuat media pembelajaran 3D?" ibu Sholihah menjawab bahwa banyak referensi aplikasi pembuat karakter yang diajarkan saat pelatihan, selain itu, pelatih sangat berkompeten dibidangnya. Hal ini dapat dilihat pada lembar angket berikut. 


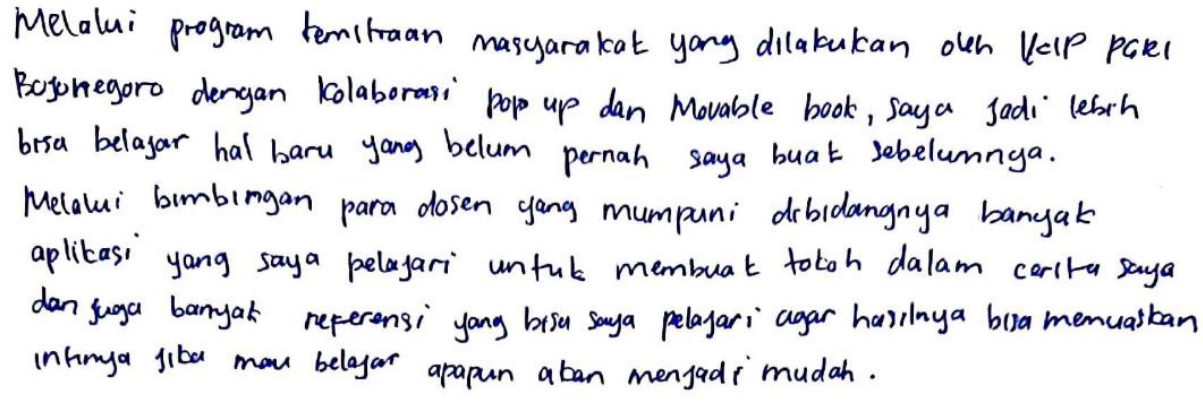

Gambar 21 Hasil angket keterampilan membuat media pembelajaran 3D

Keberhasilan pelaksanaan Pengabdian kepada Masyarakat tentang membuat media pembelajaran 3D pernah dilakukan oleh Hasanudin, dkk. (2018b) bahwa guru-guru bisa membuat media pop-up up dengan memanfaatkan aplikasi momentcam untuk menghasilkan karakter tokohnya. Hasil pengabdian Hikmah dan Selvia (2019) menyebutkan bahwa guru mampu membuat media visual gambar dengan menggunakan software.

\section{SIMPULAN}

Berdasarkan hasil pengabdian maka dapat disimpulkan bahwa 1) pengetahuan mitra pengabdian tentang media pembelajaran 3D meningkat 57\%. Peningkatan ini dapat dilihat dari perbandingan rerata hasil pretes sebesar 38\% dan rerata hasil postes sebesar $94 \%$, 2) keterampilan mitra pengabdian dalam membuat media pembelajaran 3D meningkat $70 \%$. Peningkatan ini dapat dilihat dari perbandingan rerata hasil pretes sebesar $25 \%$ dan rerata hasil postes sebesar $95 \%$.

Peningkatan pengetahuan dan keterampilan dalam membuat media 3D oleh guruguru di Desa Geger Kecamatan Kedungadem Kabupaten Bojonegoro didukung oleh materi-materi yang sudah disampaikan secara tatap muka maupun daring dengan aplikasi zoom. Materi tersebut meliputi 1) teknik menuangkan ide 2) teknik mengoperasikan beberapa aplikasi pembuat karakter kartun (momentcam, ibispaint x, dan invinite design), serta 3) teknik-teknik dalam membuat media 3D.

Hasil pengabdian ini memberikan pengetahuan kepada guru-guru tentang beberapa aplikasi pembuat karakter kartun, teknik media pop-up, dan teknik movable book sehingga dengan mengetahui ketiga komponen itu, guru-guru dapat membuat media pembelajaran 3D dan memanfaatkan media yang sudah dibuat sebagi media pembelajaran saat mengajar.

\section{UCAPAN TERIMA KASIH}

Ucapan terima kasih kami sampaikan kepada Deputi Bidang Penguatan Riset dan Pengembangan Kementerian Riset dan Teknologi/Badan Riset dan Inovasi Nasional dengan nomor surat B/87/E3/RA.00/2020 tanggal 28 Januari 2020 yang telah memberikan dana pengabdian melalui hibah PkM (Pengabdian kepada Masyarakat). 


\section{DAFTAR PUSTAKA}

Abrahamson, R. F., \& Stewart, R. (1982). Movable Books-A New Golden Age. Language Arts. JSTOR, 59(4), 342-347.

Barton, C. (2005). The pocket paper engineer. China: Main Choice International Development, Ltd.

Birmingham, D. (2010). Pop-up design and paper mechanics, How to make folding paper sculpture. East Sussex: GMC Publications, Ltd.

Brahma, I. A. (2020). Penggunaan zoom sebagai pembelajaran berbasis online dalam mata kuliah sosiologi dan antropologi pada mahasiswa PPKN di STKIP Kusumanegara Jakarta. AKSARA: Jurnal Ilmu Pendidikan Nonformal, 6(2), 97102, doi http://dx.doi.org/10.37905/aksara.6.2.97-102.2020.

Catatan Lapangan Hasil Wawancara. (2019). Wawancara dengan bapak Kamijo, 08 Agustus 2019,

Fitirianigsih, dkk. (2020). Mengelola kelas online dengan aplikasi schoology. Jurnal PKM: Pengabdian kepada Masyarakat, 3(1), 1-11. Retrieved from https://journal.lppmunindra.ac.id/index.php/pkm/article/view/5212.

Gregory, E. (2016). Pop-up cards. USA: Walter Foster Publishing

Hardjo, F. N., Retnowati, R., \& Rostikawati, T. (2017). Model pembelajaran student teams achievement divisions dengan media pop-up up card untuk meningkatkan hasil belajar biologi kelas XI IPA 1 SMA Siliwangi Bogor. Jurnal Penelitian $\begin{array}{llll}\text { Pendidikan Sains } & \text { (JPPS), } & \text { 6(2), } & \text { 1334-1339. }\end{array}$ Doi http://dx.doi.org/10.26740/jpps.v6n2.p1334-1339.

Hasanudin, C. Rosyida, F., Ermawati, S., dan Hidayat, T., (2018a). Panduan membuat media pembelajaran $3 d$ dengan aplikasi momentcam dan media pop-up up. Ponorogo, Indonesia. Wade Group.

Hasanudin, C., dkk. (2018b). Pelatihan pembuatan media pembelajaran 3d dengan memanfaatkan media pop-up up dan aplikasi "momentcam kartun \& stiker" bagi guru MTs. Bahrul ulum bulu balen. J-ABDIPAMAS (Jurnal Pengabdian Kepada Masyarakat), 2(2), 135-146. Doi http://dx.doi.org/10.30734/j-abdipamas.v2i2.305.

Hidayatullah, dkk. (2020). Implementasi model kesuksesan sistem informasi delone and mclean terhadap sistem pembelajaran berbasis aplikasi zoom di saat pandemi covid-19. Jurnal Teknologi dan Manajemen Informatika, 6(1), 44-52. Doi https://doi.org/10.26905/jtmi.v6i1.4165.

Hikmah R., dan Selvia, N. (2019). Pelatihan cabri 3d v2 untuk menigkatkan kreativitas guru dalam pembelajaran bangun ruang. Jurnal PKM: Pengabdian kepada Masyarakat, 2(2), 155-161. Doi 10.30998/jurnalpkm.v2i02.3329.

Irvine, J. (2008). How to make super pop-ups. Mineola, New York: Dover Publications, INC. 
Montanaro, \& Ann, R. (1996). A concise history of pop-up and movable books. Retrieved from https://rter.ga/ 764023-content.pdf.

Puleo, B. (2011). Next stop: Pop-ups. Pennsylvania: Marywood University.

Putri, G. F., Yasbiati, \& Pranata, O. H. (2018). Pengaruh media pop-up card terhadap hasil belajar siswa pada materi penggolongan hewan berdasarkan jenis makananya. Pedadidaktika: Jurnal Ilmiah Mahasiswa Pendidikan Guru Sekolah Dasar, 5(1),174-183. Retrieved from https://ejournal.upi.edu/index.php/pedadidaktika/article/view/7284.

Ryan, V. (2002). Pop-up card mechanisms (1). Retrieved from http://www.technologystudent.com/designpro/pop-upup1.htm.

Shofiyah, N. \& Wulandari, F. E. (2017). Pelatihan pembuatan pop-up up book sebagai media pembelajaran sains bagi guru taman kanak-kanak. Jurnal ABDI, 3(1), 32-35. Doi http://dx.doi.org/10.26740/ja.v3n1.p32-35.

Syafutri, R. \& Soeharto. (2019). Pengembangan Movable Book untuk Meningkatkan Keterampilan Proses Sains Siswa. Jurnal Pendidikan Indonesia Universitas Pendidikan Ganesha, 8(1), 141-150, Retrieved from https://ejournal.undiksha.ac.id/index.php/JPI/article/view/15640.

Van-Dyk, S. \& Hewitt, C. (2011). Paper engineering: Fold, pull, pop-up \& turn. National Museum of American History Washington, DC: The Smithsonian Libraries Exhibition Gallery.

Yuliati, N., Suhartiningsih, \& Hidayati, L. (2017). The Development of Pop-up Story Book for Improving Language Ability. The International Journal of Social Sciences and Humanities Invention, 4(8), 3750-3755.

Zubaidah, Putra, R. S., \& Gade, F. (2020). Lightening the learning climate sebagai upaya mewujudkan pembelajaran yang menyenangkan bagi mahasiswa program studi ilmu perpustakaan UIN Ar-Raniry pada mata kuliah bahasa Inggris dengan menggunakan aplikasi zoom. Indonesian Journal of Library and Information Science, 1(1), 52-62. Retrieved from https://journal.arraniry.ac.id/index.php/ijlis/article/view/528. 